\title{
Transnational Corporations as a Long-Term Factor of Economic Modernization at the Local Level (The Russian Black Sea Region Experience)
}

\author{
Nikolay W. GONTAR \\ Southern Federal University, Rostov-on-Don, Russian Federation \\ passat01@mail.ru
}

Received date:2 March 2020; Accepted date: 8 July 2020; Published date: 29 July 2020

Academic Editor: Galina Yu. Fedotova

Copyright @ 2020 . Nikolay W. GONTAR. Distributed under Creative Commons Attribution 4.0

International CC-BY 4.0

\begin{abstract}
Analysis of economic modernization processes includes a study of the role of MNCs' ties at the local level as a resource and mechanism of modernization/ The MNC and local business integration mechanisms and results in various economy sectors in the Russian Black Sea region (Rostov Region and Krasnodar Region) are analyzed in the article. The forms and tools for including MNC in the processes of restructuring the economy of the Russian Federation regions from the point of view of forming ties at the local level and of management mechanisms providing this result are analyzed for the first time in the Russian research practice. The practice analysis of more than 20 multinational corporations that came to the regions after 2000 revealed a number of patterns in organizing their presence in both regions: significant investment volumes, export orientation, formation of relations between foreign multinational corporations, business models' change compared to those in Europe. A significant number of MNC relations were established in both regions, for the reason of the agrarian orientation (which implies the counterparties multiplicity), and also owing to the MNC conditions fulfillment to localize production. A fairly active role of both regions' authorities in promoting foreign investment has been identified, a number of policy measures strengthening the ties between MNC and local economies have been identified.
\end{abstract}

Keywords: MNC, economic modernization, Black Sea region, Russia

Cite this Article as: Nikolay W. GONTAR (2020)," Transnational Corporations as a Long-Term Factor of Economic Modernization at the Local Level (The Russian Black Sea Region Experience)", Journal of Eastern Europe Research in Business and Economics Vol. 2020 (2020), Article ID 175394, DOI: $10.5171 / 2020.175394$ 


\section{Introduction}

The problem of economic modernization and the formation of conditions for its implementation remains on the agenda of the Russian scientific community and management system. In world practice, the modernization problems analysis from the 2nd half of the XX century was mainly connected with the MNC role as a significant actor in the developing and transition economies structural transformation. Relevant discussions have included not only discussions on industrialization issues, but also the problem of innovative updates through technology and experience transfer of large companies to local businesses in recent years. At the same time, the connection between the MNC sector and the national economy is discussed as a key condition for such a transfer. Targeted efforts to form such links can increase the chances of involving local producers in the relations chains and cause an increase in value-added and in the share of national value-added in exports.

The Russian specificity lies in the inherited significant industrial complex, but in modern conditions it is oriented primarily towards the extraction and export of raw materials. At the same time, the problem of modernizing the Russian economy is constantly on the agenda of both the scientific community and the management system. This task is of the greatest importance at the local level. Two key regions forming the Russian Black Sea region are considered in the article as an object of analysis: the Rostov Region and the Krasnodar Region. They, which occupy fairly strong positions in the Russian economy, have a developed economic structure and also attracted a significant number of foreign MNC in the post-Soviet period, making up a significant part of the economy regions today. The experience of forming MNC relations with local producers, the problems and factors of this process are analyzed in the article and an analysis of public administration practices at the regional level as a tool for building the ties between MNC and local producers in the interests of modernizing the economy is proposed.

\section{Methodological Framework}

The experience of analyzing and formulating modernization policies is mainly based on evidence from developing countries, but in recent decades it has also affected countries with economies in transition. Extensive theoretical generalizations of this experience, as well as empirical evidence, are contained in a series of Flagship Reports of UNCTAD (Trade and Development Report World and Investment Report, from the early 2000s). The reports provide the modernization processes analysis, as well as the role and risks of MNC participation in this process, the state policy features of regulating the MNC participation in the economy. The significance of the national approach to the economy modernization and the importance of local conditions are substantiated.

We can also note the contribution to the study of both modernization and the MNC role in this process in Russia, as well as the relationships they form at the local level as a modernization component of such researchers as Ivanter V. V. (2018), Buzgalin A.V., Kolganov I.K. (2017), Greenberg R. S. (2018).

The Russian discourse regarding modernization is focused on the structural economy transformation, but also attention is paid to the modernization of human capital and institutions. At the same time, a systematic analysis of the forms and scales of foreign MNC communication and the influence of these processes on modernization has not been carried out yet. The corresponding analysis requires an interdisciplinary approach, in particular, the analysis of MNC factors entry into the country's economy. The most popular research methods are the statistical research methods. To study the nature of the MNC influence on the local 
economy, structural-sectoral analysis was used.

The institutional approach, in turn, made it possible to analyze the practice of building state regional policy in the regions in relation to MNCs and forming their links with the local economy. Also, this approach helped to reveal how the policy of local authorities has changed in the interests of encouraging the modernization activities of MNCs.

\section{MNC links formation and local economy in the interests of modernization: features and problems}

The redistribution of influence and resources in the global economy determines the active processes of finding the positions by countries and regions. As a model of the economies' adaptive transformation in such countries, modernization restructuring with the approach to the developed countries model is considered. Industrialization and increasing the exports share are considered as tools, including the ways of attracting MNC as technology carriers and managerial knowledge. At the same time, the condition for the success of such a strategy is the presence or absence of links between foreign MNC and the national economy.

Industrialization as the most important component of the developing countries' economies modernization, as well as the transition economies' reindustrialization (based on the market principles) by means of the transnational corporations' involvement and the transfer of their experience and technologies require the fulfillment of a number of conditions for their success:

- the presence of qualified personnel capable of mastering new activities, investments in education and science in the country,

- the sufficient investment support availability for development, including the credit availability,

- the presence of a sufficient volume of demand, making localization of manufacturing industries justified.
The particular importance of relations between foreign affiliates and local suppliers is seen as a tool to maximize the benefits of export-oriented FDI as it is underlined by WIR (2002). In exportoriented economies, an increase in the MNC ties role contributes both to an increase in the technological products share in exports and in the share of valueadded created in the country in exports according to the idea of Trade and. (2016).

The process of forming MNC relations in the host economy is significantly associated with the MNC's sphere of activity. So, the mining sector MNC forms fewer bonds. Such companies use more capital-intensive technologies and processes according to the opinion of WIR (2006). However, this sector can form the relationships in the host economy in order to obtain locally produced inputs at lower cost. Business development in agricultural production can also lead to increased demand for local equipment and materials as proved by The Least. (2015).

On the contrary, the manufacturing industry has the maximum effect on linking due to the need to form the links in the areas of production, investment, knowledge and income generation (in particular: Tregenna F (2008), Structural change. (2009).

Regardless of the industry, however, MNC can have only a limited positive impact on development, in particular, due to the MNC affiliates' desire to acquire the production factors bulk from parent companies or associated suppliers, and not from the local companies. Leveling this risk is provided by stimulating the competitive suppliers of resources or MNC products' consumers network creation according to the Trade and. (2006).

A different kind of risk in increasing the FDI importance and encouraging exports may be the host countries (natural resources, cheap labor) traditional, nonprofitable, comparative advantages strengthening which does not allow achieving productivity growth and structural transformation. An example of this kind is the establishment of subcontracting relations with multinational

Nikolay W. GONTAR (2020), Journal of Eastern Europe Research in Business and Economics, DOI: $10.5171 / 2020.175394$ 
corporations or the strengthening of relations with multinational enterprises by the enterprises to the detriment of relations within the economy. Also, a wide selection of subcontractors leads to the enterprises' competition, to the buildup of benefits for multinational corporations, which reduces the benefits of foreign trade exchanges and FDI. These processes also do not imply the ties creation in the host economy. Thus, with the exception of Taiwan and Singapore, the emphasis of East Asian countries on the output production for export did not allow them to develop and strengthen feedback. With the exception of Taiwan, the export of industrial products continues to be dominated by foreign enterprises that do not maintain sufficient links with the local market and local firms according to the (Oxford Analytica (2002), Trade and ...(2002).

Trade in tolling products can contribute to the appropriation of MNC value-added, so that the actual production in the countries of foreign branches localization accounts for a small part of the exported finished products' value. For example, the transformation of Mexico and the countries of Central America into industrial assembly centers in the form of an enclave economy that is weakly connected with the country's economy (see: Gallagher and Zarsky (2007) should be mentioned here. The same can be said of the electronic and automotive industries in Eastern and Central Europe (see, for example: Pavlinek P (2015). According to Fons-Rosen et al. (2013), a serious "internal technological update" took place in the MNC branches, which, however, rarely affected the rest of the country's economy in the form of increased labor productivity or imitation activities of national companies, partly due to the MNC weaknesses with local firms and labor markets.

However, the FDI effectiveness depends on the human capital existing in the host country (Borensztein, De Gregorio and Lee, 1998); a significant positive effect of FDI on growth has been found in a number of countries with more skilled labor as proved by $\mathrm{Xu}$ (2000). The multinational corporations' arrival can ensure the knowledge and technology transfer, however - only with educated and qualified personnel availability and a significant level of demand noted in World Investment... (2006). So, in the 2000s the list of developing countries where, for example, American MNC localized R\&D was very limited: 5 countries - Brazil, China, Mexico, the Republic of Korea, and Singapore - accounted for an estimated $70 \%$ of the corresponding FDI inflows noted by WIR (2005).

As a kind of external factor, the terms of international trade, due to which, for example, most of China's previous industrial policy elements were curtailed, can be called. In particular, measures to protect fragile industries, preferential interest and tax rates, as well as some forms of direct financial assistance to industries, were abolished. With China's accession to the WTO, many JV participants in China separated from their local partners, becoming fully owned by foreign capital, which made it difficult to obtain technological and other external FDI effects indicated in the work Trade and (2006).

The complexity and variety of factors in the productive relations formation between MNC and the local economy make this sphere a priority of the management system, designed to help creating the appropriate mechanisms.

The management system goals in the MNC potential implementation as an actor of modernization

Integration into global production chains can help to master knowledge, technical modernization and industrialization if appropriate policy tools are used as proved by Trade and. (2016). Such a policy should take into account modern processes of global interaction transformation within the value chains framework, among which, in particular:

- high competition in the markets for simple products, which makes relying on export of such products less efficient today,

- the MNC attracting effect absence during cross-country competition in the situation of providing the excessive benefits and on

Nikolay W. GONTAR (2020), Journal of Eastern Europe Research in Business and Economics, DOI: $10.5171 / 2020.175394$ 
the basis of low wages, which reduces the state resources,

- the need, for the formation of the effect of attracting FDI, in the formation of a balance of MNC relations outside and inside the economy.

The lack of economic ties can often reflect the lack of a strategy to strengthen such ties, examples of which are the economies of Mexico, Costa Rica and Honduras, where export growth was not accompanied by the simultaneous development of the local industrial base (see: Summary and.. (2002). A study conducted by UNCTAD / ECLAC suggested that merely attracting FDI is fraught with the preservation of statistical comparative advantages in export activities, which have minimal connection to the domestic industry.

Due to the importance of relations with foreign branches for the dissemination of vocational skills, knowledge and technology among domestic companies, the policy in this area needs such tools as: providing information; encouraging foreign affiliates to participate in technological modernization programs; encouraging the establishment of supplier associations; joint training activities. At the same time, for example, Ireland rejects the idea of establishing communication only between local companies and foreign branches, and encourages the participation of domestic companies in the supply chains of MNC located in any region of the world according to the WIR (2001, WIR (2002).

It is significant that both the MNC attraction and the formation of their relations with the national economy can be based not only on specific policies, but also on general measures of economic development, such as: ensuring demand, investment and a stable exchange rate; assistance to training processes in the form of research and development financing, institutions of formal education and vocational training; industrialization by replacing imported intermediate products. It is also justified to turn the export processing zones into integrated industrial development parks with stronger bonds with suppliers and consumers from other economy sectors (see: Trade and...(2016).
Incentives for the production localization played a particularly important role in the first generation NIC, and especially in the Republic of Korea and Taiwan: the decision-makers of these countries sought to maximize currency and technological returns from the cooperation with transnational corporations, as well as to ensure that their activities complement, rather than replace the efforts to strengthen domestic capacity according to the Trade and...(2002).

In order to achieve the competitiveness in the increasingly technically complex output production, the leading role of private enterprises should be complemented by the support policy as it is underlined in Trade and... (2006).

\section{MNC in the Russian Black sea region: features formation of links with local economy}

The Russian Black Sea region, which, after the USSR collapse, included such entities as the Rostov Region and the Krasnodar Region, has significant economic potential all over Russia). Both regions are highly populated ( 9.8 million people totally), have a diversified economic structure, specialize in agriculture (in total, providing $12 \%$ of production in the agricultural sector of Russia). Both regions are important exporters of grain, oilseeds, vegetable oil. At the same time, industry is widely represented in both regions, including machine building, building materials industry, food industry, and metallurgy. A number of Russian companies based on the Forbes-200 largest private companies of Russia list are based here (Magnit, Neftegazindustriya, Novorossiysk Commercial Sea Port, Agrocom, Rostselmash, and other) (see in: Forbes200..). In the two studied regions, there are 10 significant ports with a total cargo turnover in 2019 of 258.1 million tons.

From the beginning of 2000 s, both regions became the areas of attraction for MNC from abroad, which contributed to the structural adjustment and renewal of the economy (Knauf, Claas, Metro Cash \& Carry, Bonduelle, Danone, Auchan, Philip Morris, PepsiCo, Tetra Pak, Alcoa, PepsiCo,

Nikolay W. GONTAR (2020), Journal of Eastern Europe Research in Business and Economics, DOI: $10.5171 / 2020.175394$ 
Guardian, IKEA, Leroy Merlin, Metro and others).

The MNC activities analysis in these regions based on the study of about 20 foreign MNC made it possible to draw a number of conclusions regarding the models and strategies for the MNC presence in these regions and their formation of bonds with the local economy. Modernization strategies of large Russian business in the South of Russia were investigated earlier (see the work of Gontar N. and Sapozhnikova A. (2019).

The factors of MNC production localization in the South of Russia in the studied regions were the concentration of demand (due to the population of the regions themselves, tourists, as well as the orientation of companies to the demand of the neighboring CIS countries, and to supply their subdivisions in Russia). For the MNC in the agricultural sphere, the geographical position, the raw materials local suppliers' network, the developed business infrastructure, human resources and the positive attitude of the regional authorities have become important. A significant factor in the MNC's part localization was reliance on local natural resources (for example, building materials).

A feature of MNC investments in the Russian Black Sea region is their significant volumes. This is due to the fact that reckoning on a significant market has stimulated MNC to create significant production volumes capable of ensuring, among other things, exporting products from the territory of the Russian Federation.

In addition, clustering is a characteristic model of localization of the MNC network in the studied regions of the Russian Black Sea region, in particular, based on the use of the significant agricultural potential of both regions. So, for example, both enterprises were established for the primary processing and transportation of agricultural products, packaging production, and for the production of final food products.
At the same time, single companies over time formed local production clusters around the base activity. Thus, the "Air Products» plant in the Rostov Region, having started the production of a full range industrial gases, also proceeded to create a modern shipbuilding and ship repair complex on the Azov Sea coast.

In addition, the interaction between MNC based in the studied regions gradually developed among themselves: for example, Cargill supplies the Russian market with high-quality chicken nuggets, as well as other chicken products, at "McDonald's" restaurants.

The initial orientation of foreign companies in both regions of the Black Sea region towards their products export was realized in the form of exporting not only industrial products (industrial gases, Guardian float glass, Claas harvester sets), but also food products and food raw materials (corn grown by Bonduelle), which significantly expands and differentiates exports of the South of Russia.

Speaking about the actual formation of relations between MNC and regional companies, two aspects can be noted: relations in the course of production localization and establishing relations with raw materials' suppliers.

For example, Claas TUCANO combines are considered to be the example of production localization: since 2018 Russian components have been installed in them (axles, combine cabins, threshing drums are next in line).

In the Krasnodar Territory packaging for Bonduelle products are produced: cans, labels, cardboard boxes. The company plans to organize the cans production for canning. (see the work of Kisin (2011).

GUARDIAN plant stimulated the development of satellite industries, small and medium businesses, and collaborates with more than 300 local companies (see: GUARDIAN.).

The most extensive bonds, however, were formed by foreign MNC in the field of 
processing agricultural products. Thus, the share of local suppliers of Krasnodar Territory in the assortment of METRO Cash and Carry in the Kuban is $21 \%$; these are meat, dairy products, cheese, seasonal vegetables and fruits. 70 Kuban suppliers work with the company (see, for example Jerry Kalmis (2018).

"Nestle Kuban" actively cooperates with more than 600 companies supplying products and services. More than half of these companies are located in the Krasnodar Region.

About $30 \%$ of potato suppliers for the PepsiCo Azov plant are enterprises in the Rostov Region. 95\% of the raw materials for Coca-Cola Hellenic in 2014 were purchased from the Russian suppliers. according to Coca-Cola (2015).

Currently, McDonald's purchases more than $90 \%$ of the products used from the Russian suppliers. In total, about 160 enterprises cooperate with the suppliers in Russia with McDonald's. Over the 27 years of operation, the company has localized almost all the deliveries of the main product categories.

Along with the establishment of broad ties in the supply of agricultural products, the considered MNCs are introducing the standards for suppliers. So, it is mandatory for the McDonald's suppliers to implement the HACCP risk analysis and the critical control point system, for agricultural producers - the basis of standards and requirements laid down in the MAAP program (see McDonald's.. (2017). A similar practice has also been established at Bonduelle.

The securing factor in the regions and strengthening ties for the companies is their cooperation with universities, vocational training, and the cognitive programs implementation ("KNAUF", "Nestle Kuban").

A characteristic feature of a number of companies' models is the change in the traditional business model to adapt to the conditions of the Russian Federation. So, "Bonduelle" today independently processes 10 thousand hectares of crops, as well as 1,5 thousand hectares - as a part of partnership programs with farmers. In Europe, "Bonduelle" has the largest share of all agriculture (99\%) in partnership projects. The company's plant in the Krasnodar Region is the only one at which vegetables are also grown. "Bonduelle" factories in Europe are engaged only in processing. This is due to the farming underdevelopment. Also, the company is trying to transfer the technologies to farmers, supporting them, buying seeds for them, providing agronomic advice, guaranteed the products' purchase. The experience of "Bonduelle-Kuban" was also taken over by the Russian canneries, which started assuming the functions of growing, which is unusual for the processors (see Kisin (2011).

A significant role in the formation of modern MNC relations in various sectors of the economy of both regions in the Russian Black Sea region is played by the management system for attracting MNC.

\section{Perspective vectors of management system development in the interests of MNC integration and local economy}

Achieving a sufficiently significant integration of transnational corporations that came to the Russian Black Sea region territory after 2000 became possible in many respects as a result of quite dynamic activity of the regional management in attracting foreign investments and supporting the investment projects' implementation. These efforts make a significant contribution to the economy modernization of both studied regions.

The most significant regional marketing tool is the annual Russian Investment Forum in Sochi, which brings together both the largest Russian and foreign companies. Also, the regional projects were presented outside the South of Russia, in particular, at the annual St. Petersburg Economic Forum, and abroad (Green Week in Berlin and others). At the same time, regional governors are actively involved in the presentation of proposals of their territories. Special zones prepared for the enterprises' location are being formed in the regions (industrial zones in the Rostov 
region, state industrial parks in the Krasnodar region).

Permanent bodies for working with foreign investors have been created and operate in the regions. The Advisory Council on Foreign Investment under the Governor has been functioning in Krasnodar region since 2004. Today, the Investment Development Agency has been operating in the Rostov Region and since 2018 the special service to support investment projects has been operating in the Krasnodar Region.

Among the permanent institutions supporting the large-scale projects in the Rostov Region is the list of « 100 governor investment projects» of the Rostov Region. Thus, the "Air Products» project, being included in the list, received support from the governor and government at all stages of its implementation.

The expansion of the «KLAAS» plant in Krasnodar was also based on the Special Investment Contract concluded in 2016 with the Ministry of Industry and Trade of the Russian Federation, specifying the terms, volume of investments and the production localization level. The regions regularly use a number of FDI support tools. So, in 2012, the Guardian plant was granted a subsidy for the cost part reimbursement of connecting to electricity and gas supply networks in the amount of 28.9 million rubles. In the Krasnodar Region, the administration assumes the coordination functions when connecting new enterprises to gas and electricity networks. The Swedish company IKEA was the first to receive individual entry conditions in the region (according to Khanova V. Kozlov V. (2011).

In connection with the effectiveness dependence of both FDI and the relations they form with local companies on the macroeconomic situation, as well as on the policies of regional authorities, the need to maintain a two-level system of measures for the participation of MNC in the modernization of regional economies can be pointed out.
So, the macro-level tasks include: stimulating demand in the economy, developing trunk infrastructure, limiting the monopolists' power in the field of energy, gas supply and facilitating administrative procedures.

It is necessary to preserve and maintain the measures in the field of mediation, dispute resolution, the formation of contacts between MNC and the scientific and educational sphere, informational assistance in establishing links between local producers and MNC at the regional level. Among the measures of assistance in the agricultural sector, the following measures should be taken: educational and training programs for local farmers, provision of agricultural services with state support, establishment of certification standards and procedures, provision of financial assistance, intermediary services for establishing links between local farmers and MNC, support for farmers' organizations as it is underlined in WIR (2008).

\section{Conclusion}

The formation of relations between MNC and local business in the Russian Black Sea region is an important mechanism for the structural transformation and export orientation of the most developed regions' economies in the period after 2000. The focus on foreign investment and the attractiveness of the Russian market have led to the arrival of a large number of MNC in the South of Russia, as well as their significant scale investments, which allowed companies not only to occupy a large part of the Russian market, but also to start exporting products. At the same time, modern changes in the geopolitical situation (tensions between Russia and MNC-based countries), as well as the Russian market pressure, can update prospective studies regarding a new range of measures to promote the development of MNC localized in the regions, forming their bonds with local producers and coordinating regional and corporate strategies.

\section{Acknowledgements}

Nikolay W. GONTAR (2020), Journal of Eastern Europe Research in Business and Economics, DOI: $10.5171 / 2020.175394$ 
The reported study was funded by RFBR according to the research project № 19010-00236

\section{References}

- Borensztein E, De Gregorio J and Lee JW (1998) 'How does foreign Direct Investment Affect Economic Growth 'Journal of International Economics, 45 (1), 115-135.

- Buzgalin A.V., Kolganov I.K. (2017) 'Planning in the 21st century economy: what and for what? 'Terra Economicus, 15(1), 25-37 (in Russian).

- Coca-Cola Hellenic increases investment in its project in the Rostov region Date of publication (2015) [Online], [Retrieved December 22, 2019], http://xn--b1aeckzdgwj.xn-p1ai/ru/news/new_element_658/ (in Russian)

- Fons-Rosen C, et al (2013) 'Quantifying productivity gains from foreign investment 'Working Paper No. 18920, National Bureau of Economic Research, Cambridge, MA

- Forbes-200 largest private companies of Russia list [Online], [Retrieved December 22, 2019], https://www.forbes.ru/rating/200krupneishikh-chastnykh-kompaniirossii-2016/2016\#all_rating.

- Gallagher KP and Zarsky L (2007) 'The Enclave Economy:Foreign Investment and Sustainable Development in Mexico's Silicon Valley. Cambridge, MA, MIT Press.

- Gontar N. and Sapozhnikova A. (2019) 'Modernization strategies of big business in the South Russia (on the example of the MNC «Novoe Sodruzhestvo») 34-th IBIMA Conference Proceedings, 13-14 November. Madrid

- Greenberg R. S. (2018) 'Some reflections on the imperatives of economic modernization in Russia 'Economic revival of Russia, 2 (56), 4146 (in Russian).

- Guardian factory in the Rostov region shipped the first commodity glass [Online], [Retrieved December 29,
2019], https://www.donland.ru/ (in Russian)

- Ivanter V. V. (2018) 'Economic growth mechanisms 'World of new economy, 12(3), 24-35 (in Russian).

- Jerry Kalmis: "METRO Cash and Carry is not going to leave Russia" (2018) [Online], [Retrieved December 19, 2019],

https://kuban.rbc.ru/krasnodar/inter view/01/03/2018/5a9785699a7947e c89de4e89 (in Russian)

- Khanova V. Kozlov V. (2011) 'What to cook from transnational 'Expert South, 39-40 (179), 45-48 (in Russian)

- Kisin S. (2011) "Bonduel-Kuban": expansion of peas 'Expert South, 29-30 (319), 25-28 (in Russian)

- McDonald's: "South farmers have great potential for cooperation" (2017) [Online], [Retrieved December 31, 2019],

https://kuban.rbc.ru/krasnodar/inter view/22/09/2017/59c4e6b19a79471 e0407080a/ (in Russian).

- Oxford Analytica (2002) 'EastAsia: Manufacturing questions 'Daily Brief, $14 \quad$ January (www.oxweb.com/default.asp).

- Pavlinek P (2015) 'Whose success? The state-foreign capital nexus and the development of the automotive industry in Slovakia. European Urban and Regional Studies. [Online], [Retrieved December 30, 2019], http://eur.sagepub.com/content/early /2014/12/09/0969776414557965.

- Production of new energy-efficient glass started at Guardian plant in Rostov region (2014) [Online], [Retrieved December 25, 2019], http://www.glassnews.info/?p=6293 (in Russian).

- Structural change and productivity growth: A review of implications for developing countries (2009) 'Working Paper. 8, UNIDO, Vienna.

- Summary and conclusions (2002). UNCTAD/ECLAC Joint Regional Seminar on FDI Policies in Latin America, Santiago, Chile, 7-9 January (www.ECLAC.org/).

- $\quad$ The Least Developed Countries 'Report 2015: Transforming Rural Economies.

Nikolay W. GONTAR (2020), Journal of Eastern Europe Research in Business and Economics, DOI: $10.5171 / 2020.175394$ 
UN Publication. Sales No. E.15.II.D.7, New York and Geneva.

- Trade and Development report 2002: Global Trends and Prospects, Developing Countries in World Trade Sales No. E.02.II.D.2 UN Publication New York and Geneva

- Trade and development report 2006: Global partnership and national policies for development Sales No: E.06.II.D.6 UN Publication New York and Geneva

- Trade and Development Report 2016: Structural transformation for inclusive and sustained growth Sales No: E.16.II.D.5 UN Publication New York and Geneva

- Tregenna F (2008) 'Sectoral engines of growth in South Africa: An analysis of services and manufacturing 'Research Paper, 98, UN University - World Institute for Development Economics Research (UNU-WIDER), Helsinki

- World investment Report 2001: Promoting linkages Sales No:
E.01.II.D.12 UN Publication New York and Geneva

- World investment Report 2002: Transnational Corporations and Export Competitiveness. Sales No: E.02.II.D.4 UN Publication. New York and Geneva.

- World Investment Report 2005: Transnational Corporations and the Internationalization of R\&D, United Nations publication, sales no. E.05.II.D.10, New York and Geneva

- World investment Report 2006: FDI from Developing and Transition Economies: Implications for Development Sales No: E.06.II.D.11 UN Publication New York and Geneva

- World Investment Report 2008: Transnational Corporations, and the Infrastructure Challenge Sales No: E.08.II.D.23 UN Publication New York and Geneva

- Xu B (2000) 'Multinational Enterprises, Technology Diffusion and Host Country Productivity Growth 'Journal of Development Economics, 62 (2), 477493.

Nikolay W. GONTAR (2020), Journal of Eastern Europe Research in Business and Economics, DOI: $10.5171 / 2020.175394$ 